$\underline{\text { Artikel Penelitian }}$

\title{
HUBUNGAN POLA KONSUMSI GLUTEN DAN KASEIN DENGAN PERILAKU HIPERAKTIF ANAK AUTIS DI KOTA AMBON TAHUN 2016
}

\author{
Glodia Waas ${ }^{1}$, Ivy Violan Lawalata ${ }^{2}$ \\ 1,2 Fakultas Kesehatan Masyarakat, Universitas Kristen Indonesia Maluku \\ Corresponding author e-mail : glodiaw@gmail.com
}

\begin{abstract}
Abstrak
Pendahuluan. Sekitar $60 \%$ anak autis mempunyai sistem pencernaan yang kurang baik, sehingga beberapa jenis makanan seperti gluten dan kasein tidak dapat dicerna dengan sempurna. Pada anak autis terjadi kebocoran dinding usus sehingga makanan diserap kembali oleh tubuh anak autis, diteruskan ke otak dan diubah menjadi morfin yang dapat merusak sel-sel otak dan menyebabkan fungsi otak terganggu sehingga meningkatkan hiperaktifitas pada anak autis. Tujuan. Mengetahui hubungan pola konsumsi gluten dan kasein dengan perilaku anak autis di Kota Ambon Tahun 2016. Metode. Desain penelitian yang digunakan adalah cross-sectional study analitik. Teknik pengambilan sampel adalah total sampling dengan jumlah sampel 32 anak. Data yang dikumpulan, meliputi data karakteristik anak autis, pola makan dan pengamatan perilaku dengan instrumen Tabel pengamatan Perilaku dan FFQ (Food Frequency Quistionaire). Analisis bivariat dilakukan dengan uji statistik chisquare. Hasil. Jumlah anak autis ditemukan lebih banyak pada laki-laki (87,5\%) dibandingkan perempuan. Status gizi pada anak autis lebih banyak dengan kategori normal $(84,4 \%)$ dan terdapat anak autis dengan gizi lebih $(6,2 \%)$ serta gizi kurang $(9,4 \%)$. Anak autis dengan perilaku hiperaktif lebih dominan $(81,25 \%)$ dibanding yang berperilaku defisit. Pola konsumsi gluten anak autis masih cukup tinggi $(62,5)$ dibanding dengan Pola konsumsi gluten $(56,2 \%)$. Hasil uji bivariat menunjukkan bahwa terdapat hubungan antara pola konsumsi gluten dengan perilaku hiperaktif anak autis $(\mathrm{p}=0.001<\alpha=0,05)$. Hasil uji bivariat menunjukkan bahwa tidak terdapat hubungan antara pola konsumsi kasein dengan perilaku hiperaktif anak autis $(p=0,064>\alpha=0,05)$. Kesimpulan. Terdapat hubungan antara pola konsumsi gluten dengan perilaku hiperaktif anak autis
\end{abstract}

Kata Kunci: Autis, Hiperaktif, Gluten, Kasein

\begin{abstract}
Introduction. About $60 \%$ of autistic children have poor digestive system, so some foods like gluten and casein can not be digested perfectly. In children with autism, leakage of the intestinal wall so that food is reabsorbed by the body of children with autism, passed to the brain and converted into morphine that can damage brain cells and cause brain function impaired, thus increasing hyperactivity in children with autism. Aims. The aim of this study was to investigate correlation between gluten and casein consumption patterns with hyperactive behavior of children with autism in Ambon, 2016. Methods. The research design used was cross-sectional study analytic. The sampling technique is total sampling with total sample of 32 children. The data collected, including data characteristic of children with autism, diet and behavioral observation with the instrument Observation Behavior and FFQ (Food Frequency Quistionaire). Bivariate analysis was performed by chisquare statistical test. Result. The number of autistic children was found to be higher in males $(87.5 \%)$ than in women. Nutrition status in children with autism more normal category $(84.4 \%)$ and there are children with autism with more nutrition $(6.2 \%)$ and less nutrition (9.4\%). Autistic children with hyperactive behavior are more dominant (81.25\%) than those who behave in deficit. The pattern of gluten consumption of children with autism is still quite high (62.5) compared with the pattern of gluten consumption (56.2\%). The result of bivariate test showed that there was a correlation between gluten consumption pattern and hyperactive behavior of autistic children $(p=0.001<=0,05)$. $\alpha$ The result of bivariate test showed that there was no correlation between consumption pattern of casein and hyperactive behavior of autistic children $(p=0,064>=0,05)$. Conclusion. There is a relationship between gluten consumption pattern and hyperactive behavior of autistic children.
\end{abstract}

Keywords: Autism, Hyperactivity, Gluten, Casein 


\section{Pendahuluan}

Autism Spectrum Disorder (ASD) adalah sebutan lengkap dari gangguan autisme, yang sesungguhnya terdiri dari beberapa macam gangguan. Deteksi dini atas gangguan ini akan sangat menentukan tumbuh kembang seorang anak. Jika didapati anak berusia di bawah dua tahun dengan kesulitan melakukan interaksi sosial (tidak bisa bermain dengan teman sebayanya), gangguan komunikasi (verbal dan non-verbal) - belum dapat berbicara atau menyampaikan keinginan secara tepat, tidak mudah memahami sesuatu, tidak merespon ketika diajak berbicara, tidak menatap atau melakukan kontak mata, yang terkadang juga diikuti gangguan sensoris dan motorik, maka sebaiknya orangtua segera memeriksakan keadaan anaknya dan tidak mendiamkan atau sekedar berharap agar semuanya akan hilang dengan berjalannya waktu atau malah menjadi panik dan marah. Tiap anak menunjukkan derajat gangguan dan kesulitan yang berbeda dan oleh karenanya diperlukan perhatian khusus. Akumulasi dari gangguan yang tidak ditangani secara dini akan berakibat pada tumbuh kembang anak yang tidak optimal dan permasalahan yang lebih kompleks di kemudian hari dengan biaya yang cukup tinggi. ${ }^{1}$

Sedangkan menurut Haniah ${ }^{2}$, hiperaktifitas pada anak autis ditunjukkan dalam perilaku yang berbeda dengan anak pada umumnya karena perilaku hiperaktif pada anak autis dapat membahayakan kesehatan anak autis itu sendiri maupun orang lain. Perilaku hiperaktif yang sering muncul adalah anak mudah marah, menangis sambil menjerit, agresif dimana anak akan memukul orang lain berulang kali, serta melukai diri sendiri.

Menurut Judarwanto ${ }^{3}$, Autisme bukanlah penyakit kejiwaan karena ia merupakan suatu gangguan yang terjadi pada otak sehingga menyebabkan otak tersebut tidak dapat berfungsi selayaknya otak normal dan hal ini termanifestasi pada perilaku autisme.

Penyebab autisme saat ini belum diketahui dengan pasti, diduga multifaktor. Akhir- akhir ini dari penelitian terungkap hubungan antara gangguan pencernaan dan gejala autisme. Sekitar 60\% anak autisme mempunyai sistem pencernaan yang kurang baik, sehingga beberapa jenis makanan tertentu tidak dapat dicerna dengan sempurna. Hasil pencernaan yang tidak sempurna tersebut dapat merusak otak sehingga memperberat gejala autisme khususnya hiperaktifitas. ${ }^{4}$

Pola konsumsi pada anak juga mempengaruhi keadaan kesehatan gizi yang dilihat berdasarkan kualitas hidangan yang mengandung semua kebutuhan akan zat gizi tersebut. ${ }^{4}$ Tetapi pada anak autis tingkat pola konsumsi harus diperhatikan pada beberapa makanan yang diduga memicu perilaku hiperaktifitas. Salah satu jenis makanan yang diduga dapat memperberat gejala autisme adalah makanan yang berasal dari protein yaitu gluten dan kasein. Gluten merupakan jenis protein yang banyak terkandung pada gandum dan terigu, sedangkan Kasein merupakan jenis protein yang terdapat pada susu dan produk olahannya. Kedua jenis protein ini sulit dicerna didalam tubuh khusunya pada anak autis karena terjadi kebocoran dinding usus sehingga protein 
diserap kembali oleh tubuh anak autis, memasuki aliran darah dan diteruskan ke otak dan diubah menjadi morfin yaitu gliadimorphin dan caseomorphin yang dapat merusak sel-sel otak dan menyebabkan fungsi otak terganggu. Fungsi otak yang terganggu adalah fungsi kognitif, fungsi reseptif, konsentrasi dan tingkah laku. ${ }^{6}$

Autisme dapat terjadi pada seluruh anak dari berbagai tingkat sosial dan kultur. Hasil survei yang diambil dari beberapa negara menunjukkan bahwa 2-4 anak per 10.000 anak berpeluang mengalami autisme dengan rasio 3 : 1 untuk anak laki-laki dan perempuan. Dengan kata lain, anak laki-laki lebih rentan menyandang autisme dibandingkan anak perempuan. $^{7}$

Hasil pemeriksaan terhadap 200 anak dengan gejala autisme di Indonesia, didapatkan bahwa seluruhnya menderita alergi makanan (multiple food allergy). Sekitar 95\% alergi terhadap susu sapi dan jenis gandum. Beberapa anak menunjukkan respons yang baik terhadap stimulasi fisik yang intensif, beberapa anak yang lain merespons terhadap pendengaran. Saat ini telah dilaporkan perkembangan yang dramatis terhadap anak yang melakukan menerapkan pola konsumsi bebas kasein dan gluten. ${ }^{4}$

Jumlah anak autis di Indonesia sampai saat ini belum akurat, data anak autis yang terdaftar di SLB menurut kementerian Pendidikan Nasional Republik Indonesia pada tahun 2009 adalah sebanyak 638 orang. ${ }^{8}$

Jumlah anak autis di Maluku berdasarkan data dari Dinas Pendidikan dan Kebudayaan
Provinsi Maluku seksi SLB Tahun 2016 terdapat 44 anak dengan autisme dan yang terbanyak yaitu 30 anak autis di Kota Ambon, sedangkan di Kabupaten Maluku Tengah terdapat 7 anak, di Maluku Barat Daya terdapat 6 anak, dan di Maluku Tenggara Barat terdapat 1 anak.

Berdasarkan data dari Dinas Pendidikan dan Kebudayaan Kota Ambon Bidang Pendidikan Seksi SLB tahun 2016, anak autis di Kota Ambon yang mengikuti pendidikan formal di Sekolah Luar Biasa maupun Sekolah Dasar adalah sebanyak 32 anak. Di SLB Kota Ambon Nania terdapat 8 anak tingkat Sekolah Dasar, di SLB Batu Merah 6 anak tingkat Sekolah Dasar dan 1 anak tingkat Sekolah Menengah Pertama, SLB Leleani 1 sebanyak 11 anak tingkat Sekolah Dasar, SLB Leleani 2 terdapat 2 anak tingkat Sekolah Dasar, SLB Pelita Kasih 1 anak tingkat Sekolah Dasar dan di SD Teladan Ambon 3 anak tingkat Sekolah Dasar.

Terjadinya peningkatan jumlah anak autis di Indonesia dan cukup banyaknya anak autis di Kota Ambon merupakan masalah kesehatan khususnya bagi anak autisme yang hiperaktif. Perilaku hiperaktifitas pada anak dengan autisme dapat membahayakan diri anak autis maupun orang-orang disekitarnya. Namun, upaya promosi dan pencegahan di bidang kesehatan terhadap munculnya perilaku hiperaktifitas serta untuk mengurangi perilaku autisme pada anak di Kota Ambon masih sangat minim. Meskipun sebenarnya berbagai upaya untuk mengurangi perilaku autisme khususnya perilaku hiperaktif pada anak autis dapat dilaksanakan sesuai dengan kebutuhan anak- 
anak tersebut. Salah satu kebutuhan dasar anak autis adalah kebutuhan akan zat gizi, yaitu dengan memperhatikan pola konsumsi makanan anak autis tersebut. Tujuan penelitian ini adalah untuk mengetahui hubungan pola konsumsi gluten dan kasein dengan perilaku anak autis di Kota Ambon Tahun 2016.

\section{Metode}

Penelitian ini menggunakan desain crosssectional study analitik (potong lintang analitik). lokasi penelitian dilaksanakan di tiga SLB di Kota Ambon dan di SD Teladan Ambon. Penelitian dilaksanakan selama 1 bulan. Populasi penelitian adalah seluruh anak autis di SLB Kota Ambon yaitu 32 anak dan sampel penelitian adalah total sampling yaitu seluruh anak autis dari populasi yang berjumlah 32 anak.

Instrumen yang digunakan dalam penelitian ini adalah lembar kuisioner sebagai lembar observasi data dengan teknik wawancara dan alat antropometri untuk mengukur Berat badan menggunakan timbangan serta tinggi badan menggunakan mikrotoise, serta tabel pengamatan Perilaku untuk menentukan tingkat hiperaktifitas anak autis dan FFQ (Food Frequency Quistionaire)untuk menentukan skor pola makan anak autis. Pengolahan dan analisis data menggunakan program spss, untuk hasil bivariat menggunakan uji statistik chi-square dan untuk menentukan kuat hubungan (korelasi) antar variabel menggunakan uji Symmetric Measure.

\section{Hasil}

Karakteristik Anak Autis di Kota Ambon Tahun 2016.

Hasil Penelitian yang dilaksanakan di Kota Ambon yaitu pada 32 anak autis yang terdiri dari $87,5 \%$ anak laki-laki dan $12,5 \%$ anak perempuan, menunjukkan bahwa jumlah anak autis dengan jenis kelamin laki-laki lebih banyak dibandingkan anak perempuan. Hal ini sejalan dengan penelitian-penelitian sebelumnya yang berbeda lokasi dimana jumlah anak autis didominasi oleh kelompok laki-laki dibandingkan perempuan dengan rasio 3:1. ${ }^{7}$

Pada penelitian ini terdapat $81,25 \%$ anak dengan perilaku hiperaktif dan $18,75 \%$ anak yang berperilaku defisit atau tidak hiperaktif. Pada penelitian ini terdapat sepasang anak kembar dengan jenis kelamin laki-laki tetapi hanya 1 anak yang mengalami autisme sedangkan saudara kembarnya mengalami tuna grahita. Menurut penelitian, anak kembar memiliki kemungkinan mengalami autisme 6095\%, tetapi dalam penelitian ini kedua anak memiliki kebutuhan khusus yang tidak sama. ${ }^{2}$

Pada penelitan ini usia anak autis yang paling banyak adalah usia 7-12 tahun yaitu $65,6 \%$ anak, dimana pada usia ini anak mulai mengerti bahwa makanan bergizi sangat berguna untuk kesehatan dan pertumbuhan. Kondisi ini dapat dicapai melalui proses pendidikan dan pembiasaan serta penyediaan kebutuhan yang sesuai ${ }^{5}$ sehingga anak-anak dengan autisme perlu mendapat perhatian khusus dan diperbiasakan mengkonsumsi makanan yang tepat dan dapat mendukung perkembangan fisik maupun kognitif anak. 
Gizi merupakan kebutuhan setiap orang, mulai dari masa kehamilan sampai dengan lansia membutuhkan zat gizi untuk melaksanakan kehidupan sehari-hari. Untuk mengetahui keadaan gizi seseorang maka perlu dilakukan pengukuran. Pengukuran yang sering digunakan untuk mengatuhi status gizi anak adalah pengukuran langsung dengan antropometri. Antropometri adalah hasil pengukuran yang spesifik mengenai ukuran dan perubahan proporsi tubuh. ${ }^{9}$ Setelah dilaksanakan pengukuran antropometri dan dilakukan perhitungan dengan rumus Z-Skor terhadap 32 anak autis di Kota Ambon, anak dengan status gizi normal berjumlah $84,4 \%$. Tetapi terdapat 9,4\% dengan status gizi kurang dan 6,2\% dengan status gizi lebih. Gizi kurang pada anak autis bisa disebabkan karena masalah sensorik, sehingga anak autisme tidak menyukai rasa dan tekstur dari makanan tertentu. Nutrisi khusus diperlukan untuk proses biokimia yang kompleks, dan nutrisi hanya dapat dicerna dan diserap dari makanan dan suplemen ketika saluran pencernaan berfungsi dengan baik. ${ }^{10}$

Pola Konsumsi Gluten Anak Autis di Kota Ambon Tahun 2016.

Berdasarkan hasil penelitian mengenai pola konsumsi gluten pada anak autis di Kota Ambon masih cukup tinggi yaitu 62,5\% anak, sedangkan pola konsumsi rendah 32,5\% anak. Penilaian skor pola konsumsi gluten ditentukan berdasarkan jumlah rata-rata skor pola konsumsi anak yaitu 70. Sehingga anak yang mengkonsumsi gluten lebih dari 70 termasuk dalam kategori pola konsumsi tinggi dan dari 32 anak yang menjadi sampel masih banyak yang mengkonsumsi gluten. Jenis makanan yang paling sering dikonsumsi adalah tempe, ayam dan tahu yang digoreng dengan tepung terigu, biskuit, kue kering dan basah yang berbahan dasar terigu, roti dan mie instan.

Seluruh anak dalam penelitian ini masih mengkonsumsi gluten tetapi dalam jumlah yang berbeda. Skor tertinggi yang diperoleh dalam konsumsi gluten adalah 90, dimana tingkat konsumsi tinggi pada makanan yang digoreng dengan bahan dasar tepung terigu, bahkan hasil wawancara dengan responden terdapat satu orang anak yang suka mengkonsumsi mie instant tanpa dimasak atau masih berupa bahan mentah.

Menurut beberapa responden selain makanan-makanan tersebut disukai anak-anak autis, karena mudah didapatkan dan harganya terjangkau. Selain itu makanan-makanan tersebut sudah terbiasa dikonsumsi sehingga menjadi suatu kebiasaan yang tidak bisa dicegah dari anak.

Pola Konsumsi Kasein Anak Autis di Kota Ambon Tahun 2016.

Hasil penelitian mengenai pola konsumsi kasein pada anak autis di Kota Ambon masih lebih rendah dibandingkan konsumsi gluten. Anak dengan jumlah konsumsi kasein yang tinggi berjumlah $56,2 \%$ anak, sedangkan pola konsumsi rendah 43,8\% anak. Rata-rata skor konsumsi kasein dalam penelitian ini adalah 35 dan skor yang paling tinggi untuk konsumsi 
kasein adalah 50. Hal ini dikarenakan pihak dari Sekolah Luar Biasa di Kota Ambon sudah memberikan edukasi terkait pola konsumsi kasein terkhususnya untuk tidak memberikan susu pada anak, meskipun beberapa makanan yang dikonsumsi masih berbahan dasar susu bahkan masih ada yang mengkonsumsi susu kental manis dan susu kemasan.

Berdasarkan hasil penelitian ini kasein yang paling sering dikonsumsi adalah cokelat, jus dengan susu, keju dan permen susu. Hal ini juga menunjukkan pentingnya tingkat pengetahuan ibu mengenai makanan yang mengandung kasein, seperti susu yang merupakan salah satu minuman yang berdampak bagi kesehatan anak autis. Tetapi, banyak ibu yang belum mengetahui banyak makanan berbahan dasar susu lainnya yang juga berbahaya bagi kesehatan anak autis, seperti cokelat dan permen susu.

Hubungan Pola Konsumsi Gluten terhadap Perilaku Hiperaktif Anak Autis di Kota Ambon Tahun 2016.

Hasil penelitian ini terdapat menyatakan hubungan yang bermakna antara konsumsi gluten dengan perilaku hiperaktif anak autis di Kota Ambon dengan nilai uji statistik $\mathrm{p}=0,001$ lebih kecil dari $\alpha=0,05$. Serta termasuk dalam kategori memiliki hubungan yang kuat berdasarkan nilai phi $=0,664$. Hal ini terlihat dari perilaku anak yang cenderung tantrum dan sering menstimulasi diri dengan bertepuk-tepuk tangan dan melompat-lompat tanpa sebab. Berdasarkan hasil pengamatan secara langsung dan wawancara dengan responden, setelah mengikuti pendidikan di Sekolah, anak terlihat lebih tenang dan tidak lagi melukai orang lain tetapi masih ada yang melukai diri sendiri dan menstimulasi diri.

Salah seorang responden mengatakan sebelum anaknya masuk sekolah anak tersebut cenderung bersikap tantrum, agresif dan self abuse dimana ia sering memukul orang lain dan dirinya sendiri bahkan sampai hampir seluruh tubuhnya terluka dan para guru mengatakan bahwa anak tersebut memakan benda yang terlihat menarik dari warnanya "waktu pertama masuk dia makan semua yang ada disini, rumput-rumput sama tanah", tetapi setelah 1 tahun mengikuti pendidikan dan orang tua mendapat edukasi agar anak tidak mengkonsumsi susu dan makanan siap saji, secara perlahan perilaku hiperaktif anak tersebut berkurang. Menurut responden, anaknya kerap mengkonsumsi makanan siap saji seperti gorengan berbahan dasar tepung terigu yang mudah dibeli dan mie instan. Tetapi setelah mulai tidak mengkonsumsi mie instan dan sedikit demi sedikit tidak mengkonsumsi gorengan berbahan dasar tepung terigu perilaku hiperaktif anak pun mulai berkurang, meskipun melalui pengamatan peneliti anak masih menstimulasi diri dengan melompat-lompat dan sesekali berteriak tanpa sebab.

Gejala hiperaktif juga dapat muncul berdasarkan makanan yang dimakan sebelumnya yang tidak dapat dicerna dengan baik oleh anak autis. Proses pencernaan yang sempurna pada orang yang normal adalah 12-24 jam dan rata-rata pada anak normal sendiri proses pencernaan anak terjadi selama 33 jam 
mulai dari mulut sampai anus, tetapi pada anak autis tidak dapat dipastikan waktu makanan dapat diproses karena adanya gangguan pencernaan maupun alergi lainnya. ${ }^{11}$

Beberapa Sekolah Luar Biasa sudah memperhatikan terkait pola konsumsi anak autis dan secara bersama-sama dengan orangtua menerapkan pola konsumsi yang sesuai untuk anak autis. Meskipun beberapa orang tua mengaku belum mampu sepenuhnya menerapkan pola konsumsi yang baik. Kepala Sekolah Luar Biasa Batu Merah memberikan edukasi kepada para orang tua anak autis agar terbiasa memberi makanan yang tidak siap saji dan makanan yang tidak setengah matang yaitu umbi-umbian yang mudah didapat seperti ubi dan singkong. Pola konsumsi ubi dan singkong merupakan salah satu bentuk terapi sederhana dari aspek nutrisi bahkan di daerah lain dilakukan bentuk pengabdian terhadap anakanak autis dengan pembuatan tepung dari umbiumbian tersebut dan tidak mengandung terigu.

Hubungan Pola Konsumsi Kasein terhadap Perilaku Hiperaktif Anak Autis

Berdasarkan hasil penelitian ini tidak terdapat hubungan yang bermakna antara konsumsi Kasein dengan perilaku hiperaktif anak autis dengan nilai uji statistik $\mathrm{p}=0,064$ lebih besar dari $\alpha=0,05$. Meskipun dalam penelitian ini perilaku anak masih cenderung tantrum dan sering menstimulasi diri dengan bertepuk-tepuk tangan dan melompat-lompat tanpa sebab tetapi berdasarkan hasil analisis skor pola konsumsi anak dengan perilaku anak tidak menunjukkan suatu hubungan. Tidak adanya hubungan berdasarkan uji statistik juga karena sudah ada pengaturan pola makanan yang mengandung kasein pada anak autis. Berdasarkan hasil wawancara dengan responden dan para guru, konsumsi kasein pada anak autis di Kota Ambon lebih rendah dibandingkan pola konsumsi gluten. Hal ini dikarenakan pihak sekolah memberi penekanan kepada para orangtua agar tidak memberikan makanan atau minuman yang mengandung kasein.

Berdasarkan hasil analisis tidak terdapat hubungan antara konsumsi kasein dengan perilaku hiperaktif tetapi berdasarkan hasil wawancara terdapat beberapa perubahan baik perilaku maupun terkait kesehatan anak autis seperti hasil wawancara dengan salah satu responden, ketika anaknya rutin minum susu anaknya mengalami sakit perut dan perilaku hiperaktif mulai muncul yaitu self abuse atau melukai diri sendiri bahkan sampai melukai orang lain, tetapi ketika mengurangi konsumsi susu dan sudah berhasil berhenti mengkonsumsi susu sekarang cenderung lebih tenang bahkan bisa memahami pelajaran di Sekolah dengan lebih cepat.

Salah satu anak juga sudah menerapkan pola konsumsi yang baik dimana mengurangi konsumsi susu, cokelat dan es krim yang merupakan makanan favorit anak tersebut, ia lebih tenang dan mampu berinteraksi dengan guru di sekolah serta teman-teman dengan baik.

\section{KESIMPULAN}

Sesuai hasil analisis dan pembahasan dalam menjawab tujuan maka kesimpulan dari hasil 
penelitian ini adalah terdapat hubungan antara pola konsumsi gluten dengan perilaku hiperaktif anak autis di Kota Ambon dilihat berdasarkan hasil uji statistik $\mathrm{p}=0,001<0,05$. Pola konsumsi gluten pada anak autis di Kota Ambon masih cukup tinggi yaitu 20 anak dengan rata-rata pola konsumsi gluten 70 dari 32 anak. Serta tdak terdapat hubungan antara

\section{Referensi}

1. HIMPSI. Jumlah Anak Autis di Indonesia. 2016.

2. Hani'ah Munnal. Kisah Inspiratif Anak-anak Autis Berprestasi. Penerbit : Diva Press. Yogyakarta. 2015.

3. Judarwanto Widodo. Jumlah Penderita Autis di Indonesia. Penderita Autis Indonesia By The Children Indonesia 2015.

4. Ginting, Sri., dkk. Terapi Diet Autisme. Vol 6, No 1. 2004.

5. Adriani, Merryana., Wirjatmadi, Bambang . Peranan Gizi Dalam Siklus Kehidupan. Penerbit : Kencana Media Group. Jakarta. 2012.

6. Pratiwi Rifmie, Dieny Fillah F. Hubungan skor frekuensi diet bebas gluten bebas casein dengan skor perilaku autis. journal of nutrition collage, volume 3, nomor 1, 2014 pola konsumsi kasein dengan perilaku hiperaktif anak autis di Kota Ambon dilihat dari hasil uji statistik $\mathrm{p}=0,064>0,05$. Pola konsumsi kasein pada anak autis di Kota Ambon lebih sedikit dibandingkan pola konsumsi gluten yaitu 18 anak dengan rata-rata pola konsumsi 35 dari 32 anak.

7. Sofia Amilia, 2012. Kepatuhan Orang tua dalam Menerapkan Terapi Diet Gluten Free Casein Free pada Anak Penyandang Autisme di Yayasan Pelita Hafizh dan SLBN Cileunyi Bandung. jurnal student e-journal unpad, Vol 1, No 12012

8. Kementrian Kesehatan RI. Pedoman Pelayanan Kesehatan Anak Disekolah Luar Biasa Bagi Petugas Kesehatan. Jakarta. 2014.

9. Barasi, M.. Nutrition at a Glance. Penerjemah : Hermin. 2009. At a Glance : Ilmu Gizi. Penerbit : Erlangga. Jakarta. 2007

10. Zahra Zulfa, Warsiki Endang. Aspek Biomedik Pada Autisme Fokus Pada Diet Dan Nutrisi. 2014.

11. Kusumayanti Dewi. Pentingnya Pengaturan Makanan Bagi Anak Autis. 2011 